\title{
Effect of increasing tannic acid addition to the diet on milk quality in the semiarid region
}

\author{
Ana Jaqueline Cavalcante MUNIZ1, Severino Gonzaga NETO', Lara Toledo HENRIQUES², \\ Roberto Germano COSTA ${ }^{1}$, Rita de Cássia Ramos do Egypto QUEIROGA ${ }^{3 *}$, Carla Aparecida Soares SARAIVA ${ }^{1}$, \\ Carla Giselly de SOUZA ${ }^{1}$, Neila Lidiany RIBEIRO ${ }^{4 \star}$ (D)
}

\begin{abstract}
The study aimed to evaluate the effect of adding tannic acid to the diet on the milk quality of cows. The five primiparous crossbred cows (Holstein x Zebu) were used, with about four years old, the average body weight of $420 \pm 30 \mathrm{~kg}, 100$ days of lactation initial average production of $18 \pm 4 \mathrm{~kg}$ of milk/cow/day. The treatments consisted of increasing tannic acid $(0 ; 1.3$; 2.6; 3.9 and 5.2\%) to replace corn bran in the diet, based on dry matter. The sensory attributes of odor had a significant effect $(\mathrm{P}<0.05)$ of the inclusion of tannic acid in the diet. The odor attributes showed a lower average for the control treatment, and these attributes also showed orthogonal contrast, except the characteristic cow, that is, the control group differed from the treatments as the tannin was introduced, the attribute value became higher compared to the control group. The inclusion of 5.2\% tannic acid in dairy cows' diet promoted a slight variation in the taste of milk. However, it did not alter the quality or acceptance of this milk by consumers.
\end{abstract}

Keywords: attributes; phenolic compounds; quality; taste; tannin.

Practical Application: With this research we observed that inclusion of tannic acid up to $5.2 \%$ in dairy cows diet did not affect the consumption of dry matter, the quality and production of milk, either nor interfered with fatty acids. However, it promoted an increase in lactose content. Atherogenicity and thrombogenicity index reveal the potential for preventing the onset of coronary heart disease.

\section{Introduction}

The milk is one of the complete foods in nutritional terms, so its quality becomes essential for human consumption due to its high nutritional value, being a source of proteins, lipids, carbohydrates, minerals, and vitamins (Food and Agriculture Organization, 2013). Technological modernization, advances in research, the intensification of legal requirements, and the consumer's concern with food quality have promoted several sectors.

The composition, physical-chemical characteristics, and, consequently, milk's sensory attributes are elements that can change, being affected by genetic, physiological, climatic, and food-based characteristics (Renhe et al., 2018). Of the various factors associated with sensory attributes and milk quality, feeding has been instrumental in handling milk components (Pereira et al., 2010), mainly regarding the lipid profile, directly affecting its taste and odor. Due to the substances present in forages with odorous properties, the pasture-based diet can modify the chemical composition and sensory properties of milk related to the composition in fatty acids and milk enzymes (Coulon \& Priolo, 2002).

Some substances modifying the sensory characteristics of milk's sensory characteristics are likely to come from intense changes in food compounds during digestion and intermediate metabolism from microbial and enzymatic processes (Addis et al., 2006). Phenolic compounds make a positive contribution to taste at a considerable concentration but tend to be unpleasant as their concentration increases (Urbach, 1997). Consequently, the presence of tannins in the feeding of ruminants can alter the food's characteristics by interfering with the ruminal biohydrogenation process, allowing changes in the volatile fraction of milk. (Delacroix-Buchet \& Lamberet, 2000). Tannins are secondary compounds of plants with antibacterial and ruminal fermentation properties, can interfere with ruminal biohydrogenation (McSweeney et al., 2001; Mueller-Harvey, 2006). Moreover, they are capable of making changes in milk's

${ }^{1}$ Departamento de Zootecnia, Centro de Ciências Agrárias, Universidade Federal da Paraíba - UFPB, Areia, PB, Brasil

${ }^{2}$ Departamento de Medicina Veterinária, Universidade Federal de Juiz de Fora - UFJF, Juiz de Fora, MG, Brasil

${ }^{3}$ Departamento de Nutrição, Centro de Ciências da Saúde, Universidade Federal da Paraíba - UFPB, João Pessoa, PB, Brasil

${ }^{4}$ Instituto Nacional do Semiárido, Campina Grande, PB, Brasil

\# In memorian

*Corresponding author: neilalr@hotmail.com 
sensory characteristics and its products depending on the type and concentration in the animals' diet (Guerreiro et al., 2015).

The role of phenolic compounds and flavonoids as antioxidant dietary components has become an increasingly important research area in human nutrition (Oliveira et al., 2014). There is growing evidence that modest and long-term intake of foods that contain phenolic compounds in their composition may have the potential to favorably modulate human metabolism, preventing or reducing the risk of degenerative diseases such as cardiovascular disease, diabetes, obesity, and cancer (Jaganath \& Crozier, 2010; Oliveira et al., 2014). The study aimed to evaluate the effect of adding tannic acid to the diet on the milk quality of cows.

\section{Material and methods}

\subsection{Experiment location and animals}

This research was approved by the Animal Use Ethics Committee (CEUA) of the Federal University of Paraíba (protocol No. 072/2016). The experiment was conducted at the Federal University of Paraíba, Bananeiras Campus, Paraíba state, Brazil (altitude $552 \mathrm{~m}$, latitude 6 $6^{\circ} 41^{\prime} 11^{\prime \prime}$, longitude $35^{\circ} 37^{\prime} 41^{\prime \prime}$ ). The air temperature was $24.97{ }^{\circ} \mathrm{C}$, and relative humidity was $76.48 \%$ in the stalls.

The five primiparous crossbred cows (Holstein $\mathrm{x}$ Zebu) were used, with about four years old, the average body weight of $420 \pm 30 \mathrm{~kg}$, 100 days of lactation initial average production of $18 \pm 4 \mathrm{~kg}$ of milk/cow/day. Before starting the experiment, the cows were dewormed and treated against ectoparasites with $3.5 \%$ Ivermectin. The animals were housed in individual stalls with $12 \mathrm{~m}^{2}$ fully covered with clay tiles, covered by concrete floor (lined with sugarcane bagasse). All stalls had a masonry feeder and plastic waterer.

The experiment lasted 100 days, divided into 05 periods of 20 days each, with 15 days for adaptation of the animals to the diets and the last 05 days to collect data and samples.

\subsection{Diets}

The treatments consisted of increasing tannic acid ( $0 ; 1.3$; 2.6; 3.9 and $5.2 \%$ ) to replace corn bran in the diet, based on dry matter. The experimental diets were formulated and balanced to meet the requirements of lactating cows with an average production of $18 \mathrm{~kg} /$ day, according to the National Research
Council (2001), offered in the form of roughage: concentrated in a fixed ratio of 64:36, respectively. Corn silage was used as roughage, and the concentrate was formulated from ground sorghum, ground corn, soybean meal, wheat bran, urea, and mineral mixture. The cows received $35 \mathrm{~kg}$ of corn silage daily as roughage, and $6.38 \mathrm{~kg}$ of concentrate composed of $3 \mathrm{~kg}$ ground sorghum, $1 \mathrm{~kg}$ ground corn, $1.5 \mathrm{~kg}$ soybean meal, $0.5 \mathrm{~kg}$ wheat bran, $0.2 \mathrm{~kg}$ urea, and $0.18 \mathrm{~kg}$ mineral mixture (Table 1 ).

The diet 0 (control) contained the sorghum cultivar BRS Ponta Negra without tannin. The other diets contained sorghum cultivar A9904, with tannin. To achieve increasing doses of tannin, PA acid (C76H52O46), tannic acid, acquired through the company Anidrol ${ }^{\circledR}$ (laboratory products), was added, as it is a source of hydrolyzable tannin. Thus, in the experimental diets (Table 2), two condensed tannin sources were offered through the two sorghum cultivars and hydrolyzable through tannic acid.

The levels of tannic acid added to the diets were established based on the analysis of the amount of condensed tannin present in the sorghum, which, according to the methodology of HCL-Butanol (Hagerman \& Butler, 1981) carried out at the Bromatology Laboratory of UAG-UFRPE A9904 (cultivar A9904) was $2.55 \%$ of total condensed tannin in DM. Control sorghum (cultivar BRS Ponta Negra) $0.92 \%$ of total condensed tannin in DM by Terrill et al. (1992) carried out at EMBRAPA Sete Lagoas - MG.

Feeding was offered at will, twice a day, at 6:00 am and 1:30 pm, right after milking, with the concentrate separated from the roughage, to ensure the total consumption of tannic acid, which was added to the concentrate, in the pre-determined proportions of $1.5 ; 79.5 ; 157.5$ and $235.5 \mathrm{~g}$, in diets $2,3,4$ and 5, respectively. The leftover feed was collected in the morning and weighed to determine consumption; the water was available to all animals ad libitum.

\subsection{Sampling of milk}

The cows were milked twice a day mechanically, at 5:30 am and 1:00 pm. Before starting milking, the teats were cleaned with water and paper towels. The first jets were discarded in the black-bottomed mug to detect possible cases of clinical mastitis. After milking, the teats were cleaned with a commercial solution of iodine and glycerin. The record of individual milk productions was performed daily throughout the experimental period, by individual weighing $\left(\mathrm{kg} \mathrm{day}^{-1}\right)$, with a scale.

Table 1. Chemical composition of the ingredients of the experimental diets (\%).

\begin{tabular}{|c|c|c|c|c|c|c|c|}
\hline Ingredient & $\mathrm{DM}$ & $\mathrm{CP}$ & $\mathrm{EE}$ & NDF & MM & NFC & $\mathrm{TC}$ \\
\hline Silage & 28.19 & 7.96 & 2.20 & 55.08 & 4.77 & 33.62 & 84.79 \\
\hline Ground corn & 86.68 & 8.97 & 4.27 & 13.98 & 1.17 & 74.47 & 80.61 \\
\hline Sorghum A9904 & 85.85 & 9.28 & 2.80 & 14.03 & 3.49 & 73.90 & 82.41 \\
\hline Sorghum control & 79.61 & 9.34 & 2.80 & 14.03 & 3.49 & 73.90 & 82.41 \\
\hline Wheat bran & 87.73 & 16.40 & 1.70 & 44.50 & 6.26 & 30.05 & 73.99 \\
\hline Soybean meal & 88.30 & 48.78 & 1.97 & 14.46 & 6.13 & 30.40 & 43.45 \\
\hline Urea & 100 & 283 & 0.00 & 0.00 & 0.00 & 0.00 & 0.00 \\
\hline Mineral mix & 100 & 0.00 & 0.00 & 0.00 & 100 & 0.00 & 0.00 \\
\hline
\end{tabular}

$\mathrm{DM}=$ dry matter; $\mathrm{CP}=$ crude protein; $\mathrm{EE}$ ethereal extract; $\mathrm{NDF}=$ neutral detergent fiber; $\mathrm{MM}=$ matéria mineral; $\mathrm{NFC}=$ non-fibrous carbohydrates; $\mathrm{TC}=$ total carbohydrates. 
From the $11^{\text {th }}$ to the $15^{\text {th }}$ day of each experimental period, three collections of $200 \mathrm{~mL}$ of milk were made from each animal, the milk collected in the morning was stored in three sterile pet's bottles kept under refrigeration at $4{ }^{\circ} \mathrm{C}$, and the one collected in the afternoon was homogenized together with the chilled in the morning, being bottled and frozen immediately $\left(-18{ }^{\circ} \mathrm{C}\right)$ (Brasil, 2000). The samples were thawed at room temperature, forming a sample composed of the milk collected from each animal for three days during the collection period (Figure 1).

\subsection{Physical-chemical and sensory analysis of milk}

The chemical analysis of fat (\%), proteins (\%) and lactose (\%) were performed using an Analyzer of Master Complete Milk (AKSO ${ }^{\circ}$, São Leopoldo, Rio Grande do Sul, Brazil), under specific technical conditions.

Table 2. Percentage and bromatological composition of experimental diets.

\begin{tabular}{lccccc}
\hline \multirow{2}{*}{\multicolumn{1}{c}{ Ingredient }} & \multicolumn{5}{c}{ Tannic acid levels (\%) } \\
\cline { 2 - 6 } 0.0 & 1.3 & 2.6 & 3.9 & \multicolumn{2}{c}{5.2} \\
\hline Corn silage (kg) & 9.87 & 9.87 & 9.87 & 9.87 & 9.87 \\
Ground corn $(\mathrm{kg})$ & 0.87 & 0.87 & 0.87 & 0.87 & 0.87 \\
Soybean meal $(\mathrm{kg})$ & 1.32 & 1.32 & 1.32 & 1.32 & 1.32 \\
Wheat bran $(\mathrm{kg})$ & 0.44 & 0.44 & 0.44 & 0.44 & 0.44 \\
Urea (kg) & 0.20 & 0.20 & 0.20 & 0.20 & 0.20 \\
Mineral mixture* $(\mathrm{kg})$ & 0.18 & 0.18 & 0.18 & 0.18 & 0.18 \\
Sorghum A9904 (kg) & 0.00 & 2.58 & 2.58 & 2.58 & 2.58 \\
Sorghum Control (kg) & 2.80 & 0.00 & 0.00 & 0.00 & 0.00 \\
Tannic acid (kg) & 0.00 & 0.015 & 0.0795 & 0.158 & 0.236 \\
Total & 15.68 & 15.48 & 15.54 & 15.69 & 15.70 \\
\hline \multicolumn{1}{c}{ Nutritional composition of the diet (bulk concentrate) $(\%)$} \\
\hline Dry matter & 36.85 & 37.30 & 37.30 & 37.30 & 37.30 \\
Crude protein & 15.55 & 15.46 & 15.46 & 15.46 & 15.46 \\
Ether extract & 1.99 & 2.08 & 2.08 & 2.08 & 2.08 \\
Neutral detergent fiber & 38.66 & 39.38 & 39.38 & 39.38 & 39.38 \\
Mineral matter & 5.48 & 5.67 & 5.67 & 5.67 & 5.67 \\
Non-fibrous & 33.68 & 33.24 & 33.24 & 33.24 & 33.24 \\
carbohydrates & & & & \\
Total carbohydrates & 68.92 & 69.27 & 69.27 & 69.27 & 69.27 \\
\hline
\end{tabular}

${ }^{\star}$ Calcium carbonate; potassium chloride; sodium chloride (common salt); ventilated sulfur (sulfur flower); Dicalcium phosphate; magnesium oxide; copper amino carbon phosphoquelate; carbo amino chromium phosphoquelate; sulfur carbohydrate phosphoquelate; carbo amino iron phosphoquelate; carbo amino manganese phosphoquelate; carbo amino selenium phosphoquelate; carbo amino zinc phosphoquelate; Butylated toluene hydroxide (BHT); Calcium iodate; manganese monoxide; sodium selenite; cobalt sulfate; copper sulfate monohydrate; zinc sulfate; vitamin $\mathrm{A}$; vitamin $\mathrm{D} 3$; vitamin $\mathrm{E}$.
For sensory analysis, samples of milk were collected from each treatment, and five sub-samples were prepared with one liter each. The milk was pasteurized, and sensorial analysis was made two days after cold storage. The sensory analysis was performed in individual booths in controlled environmental conditions, at a temperature around $23^{\circ} \mathrm{C}$ (International Standards Organization, 1988). Nine Agricultural Science students performed the sensorial taster panel, duly selected and trained (International Standards Organization, 1993). The tests took place in 3 sessions and eight trained tasters, totaling 120 samples. The milk samples were analyzed according to the descriptors present in Table 3.

The milk was submitted to sensory evaluation using Quantitative Descriptive Analysis (Stone \& Sidel, 1993). The samples were split into equal portions of $20 \mathrm{~mL}$ into polystyrene plates, marked with a random 3-digit code. A panel of tastes was organized to

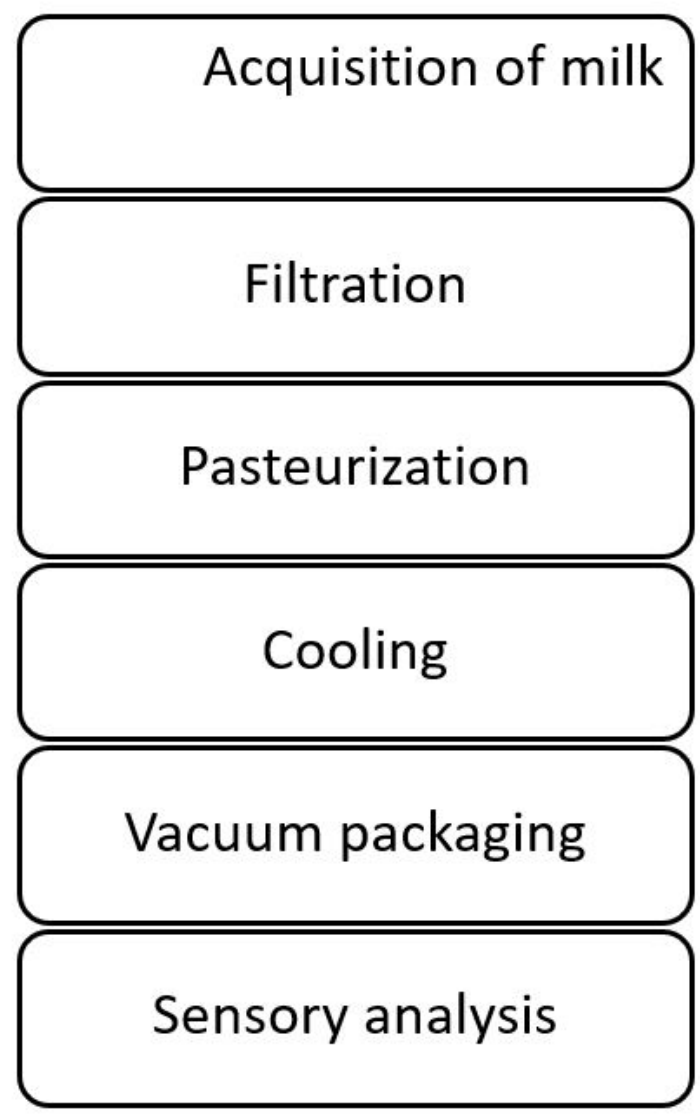

Figure 1. Flowchart of the milk process.

Table 3. Definitions of descriptors used in the sensory analysis of milk supplemented with increasing levels of tannic acid.

\begin{tabular}{|c|c|}
\hline Descriptors & Definitions \\
\hline a Odor: global intensity, Forage/Bush, Butter/Rancid, Sweet & $\begin{array}{l}\text { Organoleptic property perceived by the olfactory organ when certain volatile } \\
\text { substances are aspirated. }\end{array}$ \\
\hline $\begin{array}{l}\text { b Flavor: Global Intensity, Forage/Bush, Characteristic of Cow, } \\
\text { Butter/Rancid, Sweet; }\end{array}$ & $\begin{array}{l}\text { Complex sensation composed of olfactory and gustatory sensations perceived } \\
\text { during milk tasting. }\end{array}$ \\
\hline 'After Test: Intensity and Persistence; & Strong and striking presence of milk \\
\hline${ }^{\mathrm{d}}$ Global Acceptability & $\begin{array}{l}\text { Sum of quality attributes that will contribute to determine the degree of } \\
\text { acceptance of the product by the panelists. }\end{array}$ \\
\hline
\end{tabular}

${ }^{\mathrm{a}} 1=$ Not detected; $9=$ very intense; ${ }^{\mathrm{b}} 1=$ very hard; $9=$ very soft; ${ }^{\mathrm{c}} 0=$ very weak; $9=$ very strong; 0 = very bad; $9=$ very good. 
do the sensorial analysis, following different orders to avoid bias (MacFie et al., 1989).

Consumers evaluated the cheese samples and were asked to mark the option that best suited the product about overall acceptance using a 9-point unstructured hedonic scale. The tasters described how much they liked or disliked the attributes: odor, appearance, taste, texture, and overall impression. A scale of 5 points recommended by Meilgaard et al. (2007) was used to evaluate the intention of purchasing: 1 (Certainly I would buy it); 2 (Probably I would buy it); 3 (Maybe I would buy it/Maybe I wouldn't buy it); 4 (Probably I wouldn't buy it) and 5 (Certainly I wouldn't buy it).

\subsection{Statistical analysis}

Data were subjected to an analysis of variance (ANOVA), and the Tukey test compared the averages at 5\% probability through the PROC GLM of the SAS statistical package (Statistical Analysis System Institute, 2010). The orthogonal contrast was also used between the control and the treatments that received acids. The test Ryan-Einot-Gabriel-Welsch compared the means of the sensorial attributes $5 \%$ probability level.

After standardization, a multivariate analysis test was carried following the recommendations previously established by Sneath \& Sokal (1973) to allocate the animals into groups according to similarity and verify the original variables' discriminant capacity. The principal component analysis (PCA) allowed the assessment of overall variance, and, on the other hand, the discriminant analysis described the variation among the different groups and identified the variables with greater discriminatory power between groups. PCA was performed by the PRINCOMP (Statistical Analysis System Institute, 2010) procedure, separately for each population

\section{Results}

Milk production corrected to $4 \%$, percentage of crude protein, ash, total dry extract, defatted dry extract, $\mathrm{pH}$ milk acidity, and milk stability were not influenced $(\mathrm{P}>0.05)$ by adding tannic acid to the diet (Table 4). The dry matter intake was not influenced $(\mathrm{P}>0.05)$ by the inclusion of tannic acid in diets, which means that the maximum dose of tannic acid used in this study (hydrolyzable tannin) plus the dose of condensed tannin from the offered sorghum $(0,3210 \mathrm{~kg} / \mathrm{cow} /$ day $)$, did not cause a significant drop in palatability $(\mathrm{P}>0.05)$ to the point of affecting consumption by cows (Table 4 ). The inclusion of tannic acid in the diet of dairy cows modified $(\mathrm{P}<0.05)$ lactose. There was an increase in concentration to the level of 2.6, at the next level, a decrease in concentration, and then at level 5.2, there was an increase.

Regarding milk's sensory characteristics, the panelists' averages regarding odor, flavor, and after are listed in Table 5. It is observed that there was no significant effect $(\mathrm{P}>0.05)$ of inclusion levels of tannic acid for odor characteristics: forage/bush, flavor: overall intensity, forage/bush, characteristic cow, rancid, sweet; after the test: intensity and persistence and global acceptability.

The sensory attributes of odor (global intensity, characteristic cow, butter/rancid, and sweet) had a significant effect $(\mathrm{P}<0.05)$ of the inclusion of tannic acid in the diet. The odor attributes: global intensity, forage/bush, characteristic of cow and butter/rancid, showed a lower average for the control treatment, and these attributes also showed orthogonal contrast, except for the characteristic cow, that is, the control group differed from the treatments as the tannin was introduced, the attribute value became higher compared to the control group.

The contrast was significant for the sensory flavor attribute: global intensity presenting a lower average for the control group, differing from the other treatments. As the tannic acid was introduced, the intensity of the flavor became higher than the control treatment. The inclusion of $3.9 \%$ provided a greater global intensity with an average of 4.51 .

In the current study, taste and odor had an average score of 4.07 and 4.14 , respectively, characterizing milk as having "moderate-intensity" in these two characteristics. The scores attributed to the global assessment of the samples, although they were not influenced by the inclusion of tannic acid $(\mathrm{P}>0.05)$, indicate that the evaluated milk obtained good acceptance with an average of 4.27 considering the scale used ( 0 to 9 ). The zero showed the lowest average, representing the lowest acceptance level. The milk of cows receiving 3.9\% tannic acid had a higher average (4.72), greater acceptance by panelists to other analyzed milk. The milk samples of animals receiving 1.3, 2.6, and $5.2 \%$ of tannic acid in the diet, the acceptance averages (3.94, 4.20 and, 4.18 , respectively) were intermediately comparing to the others. The eigenvalues and the accumulated variance for each component are shown in Table 6.

Three main components were needed to explain $69 \%$ of the total variation in milk's sensory attributes from cows supplemented with tannic acid levels. Of the 13 attributes considered in the sensory analysis, 7 were important in the first 3 PCs, considering that their correlation was $69 \%$. The first principal component (PC1) explained that $29.5 \%$ of the total variance was composed of cow odor and milk production traits. The first and second principal component (PC2) explained that $51.4 \%$ of the total

Table 4. Milk production and composition of cows supplemented with increasing levels of tannic acid.

\begin{tabular}{|c|c|c|c|c|c|c|c|c|}
\hline \multirow{2}{*}{ Variable } & \multicolumn{5}{|c|}{ Tannic acid levels (\%) } & \multirow{2}{*}{ SEM } & \multicolumn{2}{|c|}{ P-value } \\
\hline & 0.0 & 1.3 & 2.6 & 3.9 & 5.2 & & Linear & Quadr \\
\hline MP 4\%, kg day $^{-1}$ & 15.71 & 15.96 & 15.80 & 15.41 & 14.74 & 0.62 & 0.15 & 0.07 \\
\hline Fat (\%) & 3.28 & 3.17 & 3.50 & 3.67 & 3.72 & 0.44 & 0.11 & 0.55 \\
\hline Crude protein (\%) & 3.45 & 3.50 & 3.27 & 3.62 & 3.28 & 0.34 & 0.66 & 0.73 \\
\hline Lactose & $4.42 \mathrm{~b}$ & $4.50 \mathrm{ab}$ & $4.77 \mathrm{ab}$ & $4.47 \mathrm{ab}$ & $4.83 \mathrm{a}$ & 0.18 & 0.05 & 0.93 \\
\hline
\end{tabular}

Different letters on the line differ from each other by the Tukey test at the $5 \%$ level; MP = milk production (corrected for $4 \%$; Quadr $=$ quadratic. SEM = standard error of the mean. 
Table 5. Sensory characteristics of milk from cows supplemented with tannic acid levels.

\begin{tabular}{|c|c|c|c|c|c|c|}
\hline \multirow{2}{*}{ Variable } & \multicolumn{5}{|c|}{ Tannic acid levels (\%) } & \multirow{2}{*}{ SEM } \\
\hline & 0.0 & 1.3 & 2.6 & 3.9 & 5.2 & \\
\hline \multicolumn{7}{|l|}{ Odour } \\
\hline $\begin{array}{l}\text { Global } \\
\text { Intensity }\end{array}$ & $3.03 c^{*}$ & $4.04 \mathrm{abc}$ & $3.23 \mathrm{ab}$ & $5.07 \mathrm{a}$ & $4.99 \mathrm{ab}$ & 5.52 \\
\hline Fodder/bush & $0.66^{*}$ & 1.17 & 1.60 & 1.99 & 2.14 & 2.76 \\
\hline $\begin{array}{l}\text { Characteristic } \\
\text { Cow }\end{array}$ & $2.41 \mathrm{~b}$ & $2.77 \mathrm{ab}$ & $2.51 \mathrm{~b}$ & 4.11 & $3.51 \mathrm{ab}$ & 3.92 \\
\hline Butter/Rancid & $1.17 \mathrm{~b}^{*}$ & $2.05 \mathrm{ab}$ & $1.88 \mathrm{ab}$ & $3.08 \mathrm{a}$ & $2.59 \mathrm{a}$ & 2.14 \\
\hline Sweet & $1.34 \mathrm{~b}^{*}$ & $1.73 b$ & $1.27 \mathrm{~b}$ & 2.91 & 2.22 & 2.10 \\
\hline \multicolumn{7}{|l|}{ Flavour } \\
\hline $\begin{array}{l}\text { Global } \\
\text { Intensity }\end{array}$ & $3.46^{*}$ & 4.27 & 4.25 & 4.51 & 4.22 & 3.54 \\
\hline Fodder/bush & 1.36 & 2.34 & 1.56 & 2.30 & 2.26 & 2.41 \\
\hline $\begin{array}{l}\text { Characteristic } \\
\text { Cow }\end{array}$ & 2.38 & 2.99 & 2.86 & 3.05 & 2.69 & 2.91 \\
\hline Butter/Rancid & 3.38 & 4.05 & 3.70 & 3.82 & 3.17 & 3.46 \\
\hline Sweet & 3.58 & 2.94 & 2.85 & 2.74 & 2.69 & 2.68 \\
\hline \multicolumn{7}{|l|}{ After Test } \\
\hline Intensity & 3.70 & 4.05 & 3.74 & 3.98 & 3.90 & 3.20 \\
\hline Persistence & 3.50 & 4.13 & 3.73 & 4.13 & 3.90 & 2.99 \\
\hline \multicolumn{7}{|l|}{$\begin{array}{l}\text { Global } \\
\text { Acceptability }\end{array}$} \\
\hline Preference & 3.94 & 4.20 & 4.31 & 4.72 & 4.18 & 2.94 \\
\hline
\end{tabular}

Tabela 6. Principal component for the sensory attributes of milk from cows supplemented with tannic acid levels.

\begin{tabular}{lccc}
\hline \multicolumn{1}{c}{ Attributes } & PC1 & PC2 & PC3 \\
\hline Odour & & & \\
Global Intensity & 0.1934 & 0.1790 & $\mathbf{- 0 . 8 4 9 6}$ \\
Fodder/bush & 0.1100 & $\mathbf{- 0 . 7 5 6 9}$ & -0.1901 \\
Characteristic Cow & $\mathbf{- 0 . 9 5 6 0}$ & 0.1271 & 0.0138 \\
Butter/Rancid & -0.0565 & 0.0559 & -0.1536 \\
Sweet & -0.2284 & 0.1500 & -0.3565 \\
Flavour & & & \\
Odour & -0.4244 & -0.1032 & 0.0866 \\
Global Intensity & 0.2002 & -0.4027 & -0.0413 \\
Fodder/bush & -0.5493 & 0.0044 & 0.5603 \\
Characteristic Cow & 0.4702 & 0.0016 & 0.2582 \\
Butter/Rancid & 0.2482 & 0.0480 & -0.0982 \\
After Test & & & \\
Intensity & 0.0700 & $\mathbf{- 0 . 7 9 4 1}$ & 0.5561 \\
Persistence & 0.1060 & -0.2872 & -0.2709 \\
Global accepatability & 0.0909 & 0.6357 & 0.3018 \\
Perfomance & & & \\
Milk production & $\mathbf{0 . 8 9 6 5}$ & -0.0382 & 0.1359 \\
Fat & -0.0233 & 0.2548 & $\mathbf{0 . 8 8 3 6}$ \\
Crude protein & 0.0355 & $\mathbf{0 . 9 8 1 3}$ & 0.0525 \\
Lactose & 0.4079 & -0.4972 & 0.4344 \\
Eigenvalue $(\lambda)$ & 2.8202 & 3.2160 & 2.7731 \\
Accumulated variance (\%) & 29.52 & 51.44 & 68.78 \\
\hline & & &
\end{tabular}

variance and the PC2 was made up of the following variables: forage bush odor, after the test: intensity and protein. The three first principal components (PC1, PC2, and PC3) explained 69\% of the total variance of the attributes.

\section{Discussion}

Factors such as the composition of dietary carbohydrates, roughage: concentrate and nature of the lipid source, breed, and lactation period resulted in changes, mainly on fat content and profile of milk fatty acids (Costa et al., 2009). The milk's fat content meets the normative instruction 62 (Brasil, 2011) requirements, establishing the minimum standard of $3.0 \%$ fat in raw milk.

The lactose variation was unexpected, once according to the literature, this component suffers the least change due to the diet, having an essential role in osmotic regulation of milk (Fonseca \& Santos, 2000). Hence, high lactose content contributes to higher milk production. Our results contradict this hypothesis. Benchaar et al. (2007) studied cow milk at the beginning of lactation, supplemented with essential oils with tannins lactose concentration in milk for the cows fed with essential oil compounds higher than those cows do not receive the supplement (4.78 vs. $4.58 \%$ ). This result suggests an effect on the rumen liquid propionate concentration, the main gluconeogenic substrate for glucose production in the liver used to synthesize lactose in the mammary gland (Berchielli et al., 2011).

Water consumption may explain the increase in lactose content. The adequate amount of water ingested is essential for the health and productivity of ruminants. However, some factors, such as tannins, may promote water consumption (Kronberg \& Schauer, 2013). The highest water intake observed in the 5.2\% treatment $(44.97 \mathrm{~L})$ probably occurred due to the astringent effects of the cows' mouth in concomitant interactions with tannins and salivary proteins. When a higher level of tannic acid was offered to the cows, they increased the water ingestion, favoring the breakdown of tannic acid and a greater supply of glucose in the mammary gland to synthesize lactose. Therefore, the increase in the percentage of lactose verified in this research may be related to the action of tannic acid on the concentration of propionate, and tannic acid is a source of hydrolyzable tannins that are more soluble in water and have a glucose nucleus in its structure (Smeriglio et al., 2017).

The milk of animals receiving tannic acid in the diet showed a more potent smell than the milk of animals receiving the control diet, suggestinga tannic acid effect on milk's smell. Therefore, the tannic acid has odorous substances that may have been transferred to the milk through the rumen (Coulon \& Priolo, 2002).

The inclusion of $3.9 \%$ of tannic acid provided a higher global intensity, a higher typical characteristic of cow's milk, a higher butter/rancid ratio, and sweet odor. However, the forage/bush score contributes to the zero levels (0.66) suggest the stability of milk to auto-catalytic oxidation reactions. Phenolic compounds have an antioxidant function, prevent or delay lipid oxidation in foods, and maintain their nutritional qualities (Danesi et al., 2008). 
A multivariate statistical procedure that considers consumers' individuality and not just the group's average and even surpasses its competitors (Stone \& Sidel, 1993) can contribute to developing adequate technologies to the sector. The technique is likely to obtain a graphical representation of the differences in acceptance between the samples on a two-dimensional scale, allowing each consumer's identification and preferences concerning the evaluated foods (Granato et al., 2012). The sensory characteristics analyzed contributes to improving the quality of the food and its maintenance, favoring consumer loyalty to a specific product in an increasingly demanding Market (Teixeira, 2009).

They evaluated color and appearance before opening, the smell and overall intensity, butter, and yogurt, which add up to $74.58 \%$. They observed that when increasing the smell and flavor vectors of yogurt, the opposite behavior of the vectors of appearance and color was verified before opening, smell - global intensity and butter, adhesiveness, and granularity, hardness, dairy flavor, and salty flavor.

\section{Conclusions}

The inclusion of tannic acid up to $5.2 \%$ in dairy cows' diet did not affect the consumption of dry matter, the quality and production of milk, either nor interfered with fatty acids. However, it promoted an increase in lactose content. Atherogenicity and thrombogenicity index reveal the potential for preventing the onset of coronary heart disease.

\section{References}

Addis, M., Pinna, G., Molle, G., Fiori, M., Spada, S., Decandia, M., Scintu, M. F., Piredda, G., \& Pirisi, A. (2006). The inclusion of a daisy plant (Chrysanthemum coronarium) in dairy sheep diet: 2 . Effect on the volatile fraction of milk and cheese. Livestock Science, 101(1-3), 68-80. http://dx.doi.org/10.1016/j.livprodsci.2005.09.009.

Benchaar, C., Petit, H. V., Berthiaume, R., Ouellet, D. R., Chiquette, J., \& Chouinard, P. Y. (2007). Effects of essential oils on digestion, ruminal fermentation, rumen microbial populations, milk production, and milk composition in dairy cows fed alfalfa silage or corn silage. Journal of Dairy Science, 90(2), 886-897. http://dx.doi.org/10.3168/ jds.S0022-0302(07)71572-2. PMid:17235165.

Berchielli, T. T., Pires, A. V., \& Oliveira, S. G. (2011). Nutrição de Ruminantes. (2nd ed.). Jaboticabal, SP: Universidade Estadual Paulista.

Brasil, Ministerio da Agricultura. (2000). Regulamento Ténico de Produção, Identidade e Qualidade do Leite de Cabra (Instrução Normativa $n^{\circ}$ 37, 8 de novembro de 2000). Diário Oficial [da] União, seção 1 .

Brasil. (2011). Regulamento Técnico de Produção, Identidade e Qualidade do Leite tipo A, Leite Cru Refrigerado, Leite Pasteurizado, Leite Cru Refrigerado e seu Transporte a Granel (Instrução normativa n ${ }^{\circ}$ 62, de 29 de dezembro de 2011). Diário Oficial [da] União, seção 1.

Costa, R. G., Queiroga, R. C. R. E., \& Pereira, R. A. G. (2009). Influência do alimento na produção e qualidade do leite de cabra. Revista Brasileira de Zootecnia, 38(spe), 307-321. http://dx.doi.org/10.1590/ S1516-35982009001300031.

Coulon, J. B., \& Priolo, A. (2002). La qualité sensorielle des produits laitiers et de la viande dépend des fourrages consommés par les animaux. Productions Animales, 15(5), 333-342. http://dx.doi. org/10.20870/productions-animales.2002.15.5.3712.
Danesi, F., Elementi, S., Neri, R., Maranesi, M., D’antuono, L. F., \& Bordoni, A. (2008). Effect of cultivar on the protection of cardiomyocytes from oxidative stress by essential oils and aqueous extracts of basil (Ocimum basilicum L.). Journal of Agricultural and Food Chemistry, 56(21), 9911-9917. http://dx.doi.org/10.1021/jf8018547. PMid:18928294.

Delacroix-Buchet, A., \& Lamberet, G. (2000) Sensorial properties and typicity of goat dairy products. Tours, France: International Association of Goat.

Fonseca, L. F. L., \& Santos, M. V. (2000). Qualidade do leite e controle da mastite. São Paulo: Lemos Editorial.

Food and Agriculture Organization - FAO. (2013). Milk and dairy products in human nutrition. Rome: FAO.

Granato, D., Masson, M. L., \& Ribeiro, J. C. B. (2012). Sensory acceptability and physical stability evaluation of a prebiotic soy-based dessert developed with passion fruit juice. Food Science and Technology, 32(1), 119-125. http://dx.doi.org/10.1590/S0101-20612012005000004.

Guerreiro, O., Dentinho, M. T. P., Moreira, O. C., Guerra, A. R., Ramos, P. A. B., Bessa, R. J. B., Duarte, M. F., \& Jeronimo, E. (2015). Potential of Cistus lodanifer L. (rockrose) in small ruminant diets: effect of season and plant age on chemical composition, in vitro digestibility and antioxidante activity. Grass and Forage Science, 71(3), 437-447. http://dx.doi.org/10.1111/gfs.12188.

Hagerman, A. E., \& Butler, L. G. (1981). The specificity of proanthocyanidinprotein interactions. The Journal of Biological Chemistry, 256(9), 4494-4497. http://dx.doi.org/10.1016/S0021-9258(19)69462-7. PMid:7217094.

International Standards Organization - ISO (1988). ISO 8589: sensory analysis: general guidance for the design of test rooms. Geneva: ISO Publications.

International Standards Organization - ISO. (1993). ISO 8586-1: sensory analysis methodology: general guidance for the selection and training and monitoring of assessors. Part 1. Selected assessors. Geneva: ISO Publications.

Jaganath, I. B., \& Crozier, A. (2010). Dietary Flavonoids and Phenolic Compounds. In C.G. Fraga (Ed.)., Plant phenolics and human health: biochemistry, nutrition and pramacology. New Jersey: John Wiley \& Sons, Inc.

Kronberg, S. L., \& Schauer, C. S. (2013). Cattle and sheep develop preference for drinking water containing grape seed tannin. Animal, 7(10), 1714-1720. http://dx.doi.org/10.1017/S1751731113001262. PMid:23880297.

MacFie, H. J., Bratchell, N., Greenhoff, K., \& Vallis, L. V. (1989). Designs to balance the effect of the order of presentation and first-order carry-over effects in hall tests. Journal of Sensory Studies, 4(2), 129-148. http://dx.doi.org/10.1111/j.1745-459X.1989.tb00463.x.

McSweeney, C. S., Palmer, B., Mcneill, D. M., \& Krause, D. O. (2001). Microbial interactions with tannins: nutritional consequences for ruminants. Animal Feed Science and Technology, 91(1-2), 83-93. http://dx.doi.org/10.1016/S0377-8401(01)00232-2.

Meilgaard, M., Civille, G. V., \& Carr, B. T. (2007). Sensory evaluation techniques (4th ed.). Boca Raton: CRC Press. http://dx.doi. org/10.1201/b16452.

Mueller-Harvey, I. (2006). Unravelling the conundrum of tannins in animal nutrition and health. Journal of the Science of Food and Agriculture, 86(13), 2010-2037. http://dx.doi.org/10.1002/jsfa.2577.

National Research Council - NRC. (2001). Nutrient requirements of the dairy cattle (7th ed.). Washington, DC.: National Academy Press. 
Oliveira, L.L., Carvalho, M.V., \& Melo, L. (2014). Health promoting and sensory properties of phenolic compounds in food. Revista Ceres, 61, 764-779.

Pereira, R. A. G., Oliveira, C. J. B., Medeiros, A. N., Costa, R. G., Bomfim, M. A. D., \& Queiroga, R. C. R. E. (2010). Physicochemical and sensory characteristics of milk from goats supplemented with castor or licuri oil. Journal of Dairy Science, 93(2), 456-462. http:// dx.doi.org/10.3168/jds.2009-2315. PMid:20105517.

Renhe, J. R. T., Pereira, D. B. C., Sá, J. F. O., Santos, M. C., Teodoro, V. A. M., Magalhães, F. A. R., Perrone, I. T., \& Silva, P. H. F. (2018). Characterization of physicochemical composition, microbiology, sensory evaluation and microscopical atributes of sweetened condensed milk. Food Science and Technology, 38(2), 293-298. http:// dx.doi.org/10.1590/1678-457x.34416.

Smeriglio, A., Barreca, D., Bellocco, E., \& Trombetta, D. (2017). Proantocyanidins and hydrolysable tannins: occurrence, dietary intake and phamacological effects. British Journal of Pharmacology, 174(11), 1244-1262. http://dx.doi.org/10.1111/bph.13630. PMid:27646690.
Sneath, P. H., \& Sokal, R. R. (1973). Numerical taxonomy: the principles and practice of numerical classification. San Francisco: W.H Freeman and Company.

Statistical Analysis System Institute - SAS. (2010). Institute SAS/STAT software. New Jersey: SAS.

Stone, H., \& Sidel, J. L. (1993) Sensory evaluation practices. London: Academic Press.

Teixeira, L. V. (2009). Análise sensorial na indústria de alimentos. Revista do Instituto de Latícinios Cândido Tostes, 64, 12-21.

Terrill, T. H., Rowan, A. M., Douglas, G. B., \& Barry, T. N. (1992). Determination of extractable and bound condensed tannin concentration in forage plants, protein concentrate meals and cereal grains. Journal of the Science of Food and Agriculture, 58(3), 321-329. http://dx.doi.org/10.1002/jsfa.2740580306.

Urbach, G. (1997). The flavour of milk and dairy products: II. Cheese: contribution of volatile compounds. International Journal of Dairy Technology, 50(3), 79-89. http://dx.doi.org/10.1111/j.1471-0307.1997. tb01743.x. 